\title{
The Representation of Character Education on Teachers' Utterances in Early Childhood Learning
}

\author{
Noor Eka Chandra*, Imam Suyitno \\ University of Lambung Mangkurat \\ Universitas Negeri Malang
}

\section{A R T I C LE INFO}

\section{Keyword:}

teachers' utterances

character education

learning

\begin{abstract}
A B S T R A C T
The purposes of the study were to determine the forms of teachers' utterances and the forms of teachers' speech techniques that represent character education in early childhood learning. The data was collected by conducting observation, recording, and interviews. The sources of the research data were four teachers who taught in the fourth grade, namely SDN Kebun Bunga 1 and SDIT Ukhuwah. The results showed that the teachers' utterances which represent character education in early childhood learning appeared in various forms of utterances and speech techniques in accordance with the context of the situation said. First, the forms of utterance that represent character education in teaching was realized through the use of dictions and the form of speech presentation. The dictions usage includes the use of the modality, the use of pronouns, the use of adjectives, and the use of verbs. In the form of the teachers' speech presentation, it included direct and indirect speech presentation. Second, the speech development techniques included repetition technique, explanation technique, and detailed technique. The character educations represented through teachers' utterance were the character of religion, discipline, hard work, responsibility, honesty, environment caring, national spirit, curiosity, intelligence, independency, social care, and tolerance.
\end{abstract}

(c) 2017 ISLLAC Journal. All rights reserved

\section{INTRODUCTION}

There is an important role on the interactive utterances between teachers and students in the learning process, as teachers can convey and explain the subject matter to the students. Through teachers' utterances, the students may develop the patterns of communication in achieving the effectiveness of teaching and learning. This statement suits on River's statement (1987:25) that states the interaction which exists between teachers as speakers and students as hearers is the key to success in achieving the objectives of teaching and learning. Further more, Chan (2013) notes the important role of the teacher in promoting interactional authenticity in the foreign language classroom cannot be achieved via a textbook.

In learning activities, teachers need to be aware that the language they use has an influence on student behaviors. Therefore, teachers need to adjust between what is said with the competence of students so that students can understand the purpose of the speech. Through this activity of speech, teachers could build the characters education of students as expected. Mirzaei and Forouzandeh (2013) said that there is a strong correlation between learners' communicative competence and language learning motivation.

In language learning, teacher speech becomes a model for students. Therefore, teachers need to provide opportunities for students to practice the language they learn and communicate with their peers. The finding of research conducted by Mitchell, et.al (2015) stated that the collaborative talk among the students is particularly useful for their language development, where they were 'scaffolding' each other's talk. In the course of the study, the students' scaffolding occurred through co-construction, other-correction and continuers, as opposed to

\footnotetext{
${ }^{*}$ Corresponding author.

E-mail addresses: nooreka_chandra@unlam.ac.id (Noor Eka Chandra), imam.suyitno.fs@um.ac.id (Imam Suyitno)
} 
comprehension checks, confirmation checksand clarification checks, which concurs with the findings of Foster and Ohta (2005).

Furthermore, Hymes (1974: 26-66) states that in reviewing the language used by teachers and students in the classroom conversation, the utterance is seen as a speech act and should be placed in the overall context of the event said related to the socio-cultural context. As a unit of utterance events, the speech act is always attached to the utterance, related to the forms, speech techniques, and the context of the events. The use of language in the utterance of teachers is closely related to the learning context utterances occurances, the characteristic of people who become the participants, the purpose of the utterances, the messages spoken, and cultural norms adopted. Differences in the context of the utterance may be implicated in a wide selection of the utterances vocabulary differences and the techniques presented in the teachers' utterance at the elementary school learning contexts in particular with regard to the integration of character education.

Character education is a matter that needs to be internalized in the process of teaching and learning. Education matters requires a process or stages in a systematic and gradual way according to the growth and the development of the students. Character education should be developed through the stages of knowledge (knowing), implementation (acting), and custom (habit) (Lickona, 1994). Hidayatullah (2010) classifies the character education in several stages, based on the hadith of the Prophet Muhammad SAW. The stages are (a) the moral planting stage (age 5-6 years), (b) the liable planting stage (age 7-8 years), (c) concern planting stage (age 9-10 years), (d) independence planting stage (age 11-12 years), and (e) the importance of community planting stage (age 13 years and over). Child morality will be formed on the first ages of life where s/he learns from parents, teachers, and the community. As stated by Hakam (2012: 87), the cultivation of moral values should be done as early as possible, therefore it can be denied that the character education should be introduced in early childhood learning. The elementary school age is a period of life which is very important for the individual morality development. SD (elementary school) is the first formal education that determines the direction of the development potential of learners in the knowledge and moral education. It is expected that the school can acts as the first step of moral teaching institution, the institution of moral training and moral values civilizing institutions (Megawangi, 2005).

Teacher is the key to the internalization of the character education to learners. The teacher is a figure that acts as a role model for students. His presence as the heart of education cannot be denied. Good or bad education relies on the teachers. Every effort should be undertaken to equip teachers to function as an actor of human civilization, driving history by giving birth to the future cadres of qualified nations plenary in the academic, affective, and psychomotor sides. In connection with that, Bellack as cited by Suwignyo, ( 2012) also states that a goal of the teachers' utterances in the learning context is to instil the good character in students' mind and heart. This means that teachers have an important role in instilling the good habit on the studenta' life. Therefore, the students will understand on which is right and wrong, be able to choose the good values and do those values in their daily life properly. The teacher's role does not merely as a teacher or academic educator, but also an educator of character, morals, and culture for their students.

However, the facts in the real life show that there is still a lot of violence to students either in the form of physical violence and verbal abuse. As revealed by Mulyadi (2016) that the field data indicates that $70 \%$ of teachers who teach really do not deserve to teach because of the violence. Mulyadi (2016) asserts that teachers should be given the skills to teach. The teachers are expected to have interesting and polite language, manners, and be creative in order to create a fun learning atmospheres for students. By the creation of a pleasant learning atmospheres, it will wake up a positive character within the students. In this situation, it is undeniable that teacher's utterances or languages have a considerable influence on the character of the students being taught.

This study was conducted with the aim to describe and analyse the utterance of teachers representing the characters education in early childhood learning. The problems of the study included (1) the teachers' utterance forms that represent the character education and (2) speech techniques presentation that represent the teaching of character education in early childhood.

\section{METHOD}

The research was conducted using descriptive qualitative study design. Teachers' utterances to the student in the context of learning in fourth grade was the object of this study. There were 4 teachers who became the subjects in this study. They are the teachers of SDN Kebun Bunga 1 and SDIT Ukhuwah Banjarmasin. Children who are in the fourth grade is a proper representation in terms of learning in early childhood. The data collection was carried out by conducting observation, recording, and depth interviews with the teachers. In collecting the data, the researcher acted as the key instrument equipped with a manual observation, interview, and electronic recording devices. Observation methods was used to obtain data on teachers' utterance that was not recorded by the audiorecorder. Observation method was created in the form of passive participatory methods. Depth interview method was used to supplement the data which was not observed or recorded in the observation sheet. The process of data analysis was conducted in few stages such as (1) data collection, (2) data reduction, (3) the presentation of the data, (4) the tentative conclusion drawing, and (5) the conclusion of the final study findings. Thus, the process of data analysis and conclusions were made from the beginning to the end of the research.

\section{RESEARCH FINDINGS}


The research findings included the description and the result of analysis of the teachers' utterances and the teachers' uttering techniques that represent education character. The research findings are as follows.

The Form of Utterances Representing Characters Education in The Context of Early Childhood Learning

Data description of teachers' utterances that represent the character education found in the field. It was realized formally through two language use, namely the use of diction and the form of speech presentation. The use of diction in teachers' utterances which represent the character education manifested on the modalities, pronouns, adjectives, and verbs. There were two types of speech presentation in a learning context that represent the character education, namely the direct and indirect speech presentation.

a. Modality

Modality is an information within a statement in a sentence that expresses the attitude of teachers towards students related to the matters discussed during the teaching and learning. Based on data of the study, it was found that teachers often used modalities in expressing utterances to students. Forms of the utterances that represented character education stated by the teachers were realized through (a) the use of modality in the form of want, (b) the use of modality in the form of hopes, (c) the use of modality in the form of asking, (d) the use of modality in the form of invitation, and (e) the use of modality in the form of command.

\section{1) Modality of Want}

Based on data, it was found that there were teachers' utterances with modality, and the modality disclosers were want and desire. Here is the data presentation of the utterances which contain the modality of want. Quotation [1]

(1) Ibu menginginkan kalian untuk mendengarkan penjelasan Ibu lebih seksama. (2) Ibu harap kalau ibu lagi menjelaskan ..jangan masing-masing bicara.......supaya apa...?(3)Supaya apa yang sedang ibu jelaskan kalian bisa mengerti.

((1) I want you to listen to the explanation more carefully. (2) I hope that if I am explaining something, you will listen carefully. Why is that so? (3) Because I want all of you understand)

The spoken above takes place when teacher explained to students and ask them to listen more carefully. In this utterance, it appeared that the teacher was using modalities showing desire by saying menginginkan "want" as seen in the quotations [1] data (1). There, through the teacher's utterance, she wanted the students to listen to the explanation given by the teacher carefully. Based on the interviews with teacher, the reason she expressed the utterance was because there were several children who talked to each other when the teacher was explaining the materials at that time. The teacher considered it was necessary to be expressed so that students knew the teachers' concerns. The utterance was strengthened again with the use of the modality which has expectations meaning with the discloser of modality harap "hope" (data utterances 2). It meant that the teacher expected the students to listen to the teacher's explanations in order to understand more about the material being delivered at the time.

\section{2) Modality of Hope}

In the utterance of data found in the field, there was a teachers' utterance which contain modality which has a hope meaning. The disclosers of the modality were hope, expect, prayer, and pray. The following data is the utterances containing modality with hope meaning.

Quotation [2]

(1) Ibu mengharapkan kalau jam istirahat, jangan makan di kelas. (2)Makannya di luar kelas saja supaya kelasnya tidak kotor.

((1) I expect that during the recess, do not eat in class. (2) Please eat outside, so that the classroom will not be dirty.)

The spoken above takes place when teacher saw there were some students who ate in the classroom during recess. The use of the hope modality can be seen in quotation [2] with the discloser modalities mengharapkan "expect" and supaya "so that". The purpose of the utterance was that the teacher expected the students to eat outside of the classroom during recess so that classrooms would not be soiled by food junk. The hope modality utterance used by the teachers was one of the speech acts in the form of prohibition. Based on data from interviews, the teacher believed that the use of utterance in the form of a prohibition, such as jangan 'do not' or 'should not be', was more effective when it was expressed at the time the students were doing it. This is because they could easily understand the teacher's expectations on the condition at the time. This can be seen in the utterance data [2] when the teacher forbade students to eat in the classroom during recess. However, to soften the power of illocutionary within the utterance, the teacher used the modality "expects" before saying "do not". It was aimed to reinforce what was meant by the teacher at the time of delivering the previous utterance. In the utterance, it can be seen as that in classroom context, the teacher had the capacity to enforce a code that have been agreed in advance.

3) Modalities of Asking/Invitation

Invitation is an utterance expressed by the teacher to the students whose goal is to encourage students to do something related to the learning process. The disclosers of modality with invitation meaning were let's and come on. Here are examples of utterance that contains the modality let's and come on.

Quotation [3]

Teacher : (1) Semuanya masuk? (Everyone is present, right?)

Student : (2) Aan tidak masuk Pak. (Aan is absent, Mr.) 
Teacher : (3) Apa ada yang tahu dia ke mana? (Anybody got news about him?)

Student : (4) Aan sakit, Pak. (Aan is sick, Mr.)

Teacher: (5) Oh iya, ayo kita berdoa supaya Aan segera sehat. (Oh, then let's pray so that Aan will get well soon). (6) Farid silakan memimpin doa. (Farid please lead the prayer.)

The spoken above takes place when teacher checking the presence of students in early learning. In the quotation [3] data (5), the teacher asked the student to pray for their friend who was sick. Modalities used was ayo "let' s" which means the invitation to do an activity together. Based on the data taken by interview, the teacher believed that this was necessary to be trained by the teacher, therefore the students would have an attitude of caring toward each other. One way was by getting the students to pray together to Allah SWT in order to asking for health for their friend. This activity trained the students' empathy indirectly.

\section{4) Modality of Demand}

The teacher also often used modality for the purpose of demand to students for doing something. In a certain context, the teacher used multiple modalities in her utterance with the intention that the students would do what was asked by teachers based on teachers' concerns at the time of the context of the utterance occurred. Modality usually used by the teacher were saya minta "I demand", silakan "please" and coba "try". The use of modalities such requests could be seen through the following utterances.

\section{Quotation [4]}

$T$ :(1) Ibu minta agar kalian segera menyelesaikan gambarannya karena waktunya sudah mau habis. (I demand that you complete the picture immediately as the time is about to run out.)

Ss : Iya Bu(Yes Ma' am)

(Context: Spoken by teacher at the time of drawing lessons and lesson time was going over)

\section{Quotation [5]}

(1) Rafa, silakan berbicara yang keras supaya teman kalian bisa mendengarkan. (2) Coba

berbicara lebih keras lagi. (Rafa, could you speak louder, please. So, your friend can hear what you say. (2) Try to speak louder, please!)

(Context: Spoken by teacher at the time when she asked a student to read aloud and at that moment the student' s voice can't be heard clearly).

Based on the utterance above, it can be seen that the form of utterance expressed by teacher was a request to the students to do something as expected or desired by the teacher. This was disclosed by the teacher in an interview, that by the use of the modality expressed in utterance, the students would understand the requests more easily. The use of appropriate modalities would facilitate students to understand the meaning of the utterance delivered at the event occurred. In quotation data [4], the teacher used demand modality expressed by the word "I demand", which the purpose was asking students to quickly complete the drawing task. The teacher demanded immediate response by students to answer "Yes ma'am" meaning that they affirmed what was required by their teacher at the time. It also appeared that the student responded when the teacher delivered her request that student was asked to read the text a bit louder [quotation 5 data 1 and 2]. The Discloser modality of the utterance quote [5] can be seen through the utterance data (2) on the use of the modality "try".

\section{5) Modalities of Command}

Giving command was one of the frequent teacher's utterances to the student with the aim that the student immediately implemented what was ordered by the teacher at the time being. Commanding utterance was expressed through the use of the modality then, come on, should be ordered, prohibit, prohibited, must not and do not. The following data is the examples of the utterances with command modality.

\section{Quatation [6]}

$T$ :(1) Oval, ingatkah dengan PR? (2) Padahal, saya pikir kemaren sudah sangat jelas ibu minta harus dikerjakan PR-nya.(3) Hari ini kita membahasnya. (4) Ayo Oval kerjakan! ((1) Oval, do you remember the homework? (2) I thought it was very clear that Mrs asked all of you have to do the homework. (3) Today we will discuss it. (4) Come on, Oval. Do it now!)

Ss : (5) Inggih $\mathrm{Bu}$ (Yes Ma' am)

(Context : Spoken when the teacher gave orders to one of the students when they were checking homework given on the previous day.)

\section{Quotation [7]}

(1)Kalau teman-temanya membaca doa, jangan bicara!. (2) Ikuti teman temannya berdoa, tujuan kita berdoa itu supaya kita pintar, supaya belajar kita bermanfaat. (3) Ayo diulang lagi berdoanya dengan betul! (1) If your friends are reciting a prayer, please do not talk! (2) Follow your friends to pray. We are pray so that we will be smart, and what we learn will be useful. (3) Let' s repeat the prayer correctly!)

(Context : Spoken by teacher at the initial stage before the learning process begins.)

In the quotation [6], the teacher used the modalities such as saya pikir "I thought", harus "have to" and ayo "come on" in utterance (2) and (4). This was done with the intention of giving orders to the students to do homework 56 | ISLLAC : Journal of Intensive Studies on Language, Literature, Art, and Culture 
assigned the day before. In order to softening the power contained in the utterances, teacher used the modalities of " $I$ thought" (1) and "come on" (4). On the use of the modality of "have to" in utterance (2), it can be seen that the teacher required the students to do homework timely as desired by the teacher, one the day before the homework would be discussed together.

In the qoutation [7] the teacher used modalities jangan "do not" in utterance (1) with the intention of asking students not to talk during the times of prayer. The use of the modality of "do not", according to theory, could be categorized as acts of commanding, however in the context of utterance (1) it can be seen that there was a request from teachers based on the context of the utterance produced. The request was reaffirmed by the teacher by using the modality of "so" and "come on" in utterance (2) and (3). This meant that the teacher intended to make students understood better the reason why the teacher expressed the utterance to them. The Meaningful use of hope modality is also seen in the utterance [7] by the use modality "that". The intention of the utterance is to make students achieve the learning objectives as expected by the teacher. The use of the modality "that" means as teachers hope that one purpose of prayer was to be smart students and the lessons learned could be useful for them. Teacher repeated the command to repeat the prayer with the use of the modality of ayo "let" commanded at the beginning of the sentence aimed at students (utterance 3).

\section{b. The Use of Pronouns}

Based on data, it was found that teachers often used pronouns. In the use of pronoun, it can be divided into three types, which are (a) the proper names of God, (b) the personal pronouns, and (c) terms of addresses. First, the proper names of God is a pronoun associated with the god or religion. Pronouns used to talk about divinity were AllahSWT and God.

\section{Quotation [8]}

(1) Ingat ya anak-anak...kita berdoa itu merupakan salah satu cara kita bersyukur kepada Allah SWT. (2) Kita sudah diberi nikmat sehat...jadi bisa hadir di sekolah hari ini, nikmat kepandaian..jadi bias belajar hari ini. (3) Jadi rajin rajin berdoa...supaya ditambah Allah lagi nikmat-Nya kepada kita

((1) Remember kids ... we have to pray, and it is one way we thank Allah SWT. (2) We have been given healthy ... so we can come to school today. We' ve been blessed with cleverness.. So, we can learn today. (3) So, be diligent in reciting the prayer ... Allah will give His blessing to us more and more.)

(Context: the use of pronoun Allah was told by teacher at SDN KB 1 at beginning of the learning activities and she asked to the students to be more devoted in worshipping the God)

In the utterance above shows, the teacher uses the proper names of God that is Allah SWT. This means that teachers educated students to always behave religiously by praying to God for He has given many favours. The use of pronoun Allah "His" in the utterance above also refers to God as the pronoun of Allah SWT. In this utterance, it can be seen that the teacher taught students about morality to Allah SWT that Allah SWT was the One who gave grace and gave torment to anyone He would. The teacher brought awareness to students that human owed Allah SWT for His countless bestowing grace which was needed by humans, therefore the human had obligation to obey Him and be grateful for all His gifts.

Second, personal pronoun is a pronoun used to refer to people. Based on the data in the field, it was found out that the pronoun was commonly employed by the teacher was the first person singular pronoun, the third person singular, the first plural person, and the second person pronouns. Here's one example of the utterance using the personal pronoun.

\section{Quotation [9]}

(1) Ass. Wr. Wb ...... Puja ... (2) perhatikan ke sini....di mana papan tulisnya? Apa yang ada di papan tulis? Jika saya dii depan, perhatian kalian harus ke depan (3) jangan memperhatikan ke mana-mana. (4) Ibu ingin kalian memusatkan perhatian ketika ibu menerangkan pelajaran. ((1) Ass. Wr.Wb... Puja...(2) Pay attention, please ... Where is the blackboard? What's on the back? If I am in the front, your attention should be ahead. (3) Don't go anywhere else! (4) Mrs wants you to focus your attention when lam explaining the lesson)

(Context: The use of the pronoun "Puja" spoken by the teacher when she saw one of the girls was not paying attention to the whiteboard)

The data above shows that the teacher used the third person singular pronoun by saying the name of Puja whom she interacted with at the time. The use of the student's name who was invited to speak served to reduce the social distance between the teacher as speakers and the student as hearer. It resulted that the utterance was expressed noticeably more refined. It as well would provide a softening effect on the illocutionary power within the utterance the teacher expressed at that time.

Third, terms of adresses is a pronoun used to remind the people whom someone interacts with or to replace the name of a third person. In the context of learning in the classroom, terms of addresses was often used by teacher when she said something to the students. Terms of adresses often used was the Mrs, Ustadzah, children or the student's name. Below is the excerpt of utterance of the greeting.

\section{Quotation [10]}

(1) Oval, kalian tidak lupa PR-nya? (2) Ibu pikir sudah jelas bahwa ibu minta kalian semua harus mengerjakan PR. (3) Hari ini, kita bahas. (4) Ayo, Oval, kerjakan! (Oval, do you remember the homework? (2) Mrs thought it 
was very clear that Mrs asked all of you have to do the homework. (3) Today, we discuss it. (4) Come on, Oval. Do it!)

(Context: The use of the pronoun 'Mrs' was spoken by the teacher when she learned there was one student who did not finish the tasks given previously)

In the context of early childhood learning in fourth grader, terms of addresses which was commonly used by teachers as a speaker when interacting with students was Ibu or Ustadzah. The terms of addresses that commoly used are the first singular person pronoun. This suggests that teacher as a speaker identified herself as one of the group within the hearers, therefore there was reason for teacher to govern or ask the students to do something. She also intended to soften the illocutionary power contained within the utterance expressed at that time, thus the utterance sounded politer than if she used the first-person pronoun $I$. The use of pronoun Ibu and Ustadzah also indicated that the speaker was already has close relationship with the participants.

c. The Use of Adjectives and Verbs

Based on the data, it was found that in her utterances the teacher often used adjectives and verbs with the aim of clarifying the meaning said at the time. The use of adjectives and verbs related to three types, which are (a) the usage of adjectives and verbs that related to the development of students characters in the term of God, (b) adjectives and verbs usage that related to the character development of students' personality, and (c) the usage of adjectives and verbs that related to the character development of students' life in society. One of the characters which was always instilled by the teachers was the habit of always conducting worship to God, both at school or out of school. There are few adjectives and teachers can use to develop the character of students in Divinity. It can be seen in the following examples.

Quotation [11]

Guru

Siswa

:(1) Zuli di rumah sholat berjamaah kada?

Guru

:(2) Inggih Ustadzah ai

Siswa

: (3) Ya bagus dapat bintang. (4) anak-anak tahu kan kenapa kita harus sholat berjamaah ?

Guru

: (5) Supaya dapat pahala Ustadzah ai

: (6) Iya betul karena kalau kita sholat berjamaah pahala yang akan

didapatkan lebih banyak daripada pahala sholat sendirian. Sebagaimana Ibnu Umar meriwatkan bahwa Rasulullah SAW bersabda, "Shalat berjamaah itu lebih utama 27 derajat dibandingkan shalat sendirian. (7) Nah ini hadis dari Bukhari dan Muslim. (8) Bahkan dikatakan bahwa setiap langkah kaki kalian ke masjid itu dicatat satu pahala dan menghapus satu kesalahan. (9) Nah banyak kan pahala yang didapat.

Siswa : (10) Ustadzah mun sholat berjamaah nya di rumah aja pang... dapat jua lah pahalanya

Guru : (11) Insya allah dapat aja...yang penting kita ikhlas. (12) Jadi Ustadzah minta kalau sembahyang itu berjamaah supaya pahala yang kita dapatkan lebih banyak lagi daripada sembahyang sendirian aja. Dengan begitu keimanan kita akan bertambah kuat lagi. Anakanak Ustadzah akan menjadi anak yang beriman kepada Allah SWT

Teachers: (1) Zuli, did you pray at home?

Student : (2) I did, Ustadzah.

Teacher : (3) Yes. You get a star. (4) children, do you know why we should pray?

Student : (5) to get reward, Ustadzah.

Teacher :(6) I... yes that's right because if we pray together, we will get more reward than praying alone. As Ibn Umar narrated that the Prophet Muhammad SAW said, "Praying together is 27 times more worthy compared to praying alone. (7) This is the hadith of Bukhari and Muslim. (8) It even states that every footstep you make to the mosque was recorded as one reward and remove the sin. (9) So, you will obtain a lot of merits.

Student: (10) Ustadzah, if we pray together at home, do we get the reward, too?

Teacher: (11) Insha Allah, as long as you do it sincerely. (12) So, Ustadzah wants all of you to pray

in congregation, so that the reward that we get will be more than just if we do the prayer alone. It will make our faith grows strong again. Ustadzah's children will be children who believe in Allah SWT.

(Context: The use of prayer in congregation (Shalat berjamaah) was spoken by the teacher when they were discussing about the primacy of prayer in congregation. The word Sincere was to describe the conditions that the students must feel in performing worship. The words strong and faith refer to the belief in Allah SWT in performing worship)

From the data, the way the teacher provided direction and guidance on religious activities normally carried out by a good Muslim is visible. The use of diction which is both literal and denotative was used by the teacher as a way of expressing what was meant to be conveyed by the teacher at the time. In the uttering event, the teacher should choose right words to describe the topic.

Based on the Grice principles of cooperation, the utterance has also been right. Excerpts of qoutation [11] have already been obeying the maxim of quality because the dictions usage such as congregational prayer, 5 times, not broad, sincere, tumani'nah, growing stronger, and faithful are associated with the character building of students in 
divinity. In the maxim of quality, a speaker must be able to choose the right words to describe the intent that he expresses in utterance during speech context occurs. In the utterance, it is visible that through the appropriate choice of adjectives and verbs diction, the teacher tried to build a pattern of interaction to achieve the effectiveness of learning.

The adjectives and verbs related to the students' personality are usually used by teacher to explain the conditions associated to the character development of the personality of students. This can be demonstrated by the following diction.

Quotation [12]

Guru : (1) Coba belajar menghitung sendiri, belajar jujur...kan gasan buhan pian jua kaina.

(2) Ayo dihitung sendiri- sendiri! Insya Allah kalau kalian jujur maka nantinya akan

lebih sukses di masa yang akan datang. ( (1) Try to learn calculating it on your

hidup

to be honest ... That' s going to be for your own good. (2) Come on! calculate

own, learn

individually! Insha Allah if you are honest, you will live more successfully in the future.

(Context: Spoken when the teacher asked students to be honest in doing task)

Based on the utterance above, it is obvious that the teacher used the diction with the honesty meaning as the intent of the topic at the time the context of the utterance occurred. The use of appropriate adjective to develop the students' character would make the utterances stated by the teacher understood more easily. The use of dictions honest, come on, count on your own literally and denotatively was aimed to make the students do their assignment or examination by relying on their own ability and not by cheating. This is understandable because the teacher believed that if they want to succeed in life, the character of honesty should be held well by the students. The main purpose of an education is a form of honesty, because honesty is the basic capital in a common life and the key to the success of is honesty. The teachers believed students who are nurtured early can learn, understand, and realize the balanceharmony.

\section{Teachers' Speech Presentation Representing Characters Education in The Context of Early Childhood Learning}

Based on the data, it was found that the forms of speech presentation that represent the character education can be divided into two forms, namely direct presentation and indirect presentation. In this research, the indicator of teachers' direct speech presentation representing the character education was the declarative sentences is a sentences that declare something, interrogative sentences is a sentence that ask something and imperative sentence is a sentence that command something from them.

\section{a. Direct Utterance Presentation}

The data found in the field showed that the presentation of direct utterance expressed by teacher in the learning process of early childhood tended to be imperative sentence. Generally, the teacher used imperative sentences with an aim to the requested action to students as the hearers can be directly carried out or undertaken it. This can be seen as in the following example.

Quotation [13]

(1)... Ayo, Oval kerjakan! (....Come on, Oval do it!)

(2) ... Hitunglah sendiri (.....Calculate it on your own!

The utterance of the data showed that the form of direct utterances function as a command for hearer to do the homework assigned (1), and to calculate math assignment individually (2). The utterancess (1) and (2) which were spoken by the teacher to students is an evidence that the teacher had applied the character of a discipline, responsibility, and independence to the students in completing the tasks given during the learning process. The reasons why the teacher often use the direct utterance presentation in classroom interaction as it has a clear and straightforward way, therefore the students could easily understand the intention of the teacher's utterance. In addition to the imperative form within the form of direct utterance presentation, teacher also used the direct utterance presentation in form of declarative sentences that explained about something to be done by the students during the learning process. By the term, declarative sentence is a sentence that contains a statement that serves to provide information or news about something. In this context, it was something related to the learning process in the classroom. The use of direct presentation in the form of declarative was intended to create the same understanding on the meaning or purposes of the utterances that expressed by the teacher during the learning process. This can be seen in the data below.

Quotation [14]

Siswa : Bu apa maksudnya proses terjadinya pemuaian itu Bu ?(Ma' am, what does the process of expansion means?)

Guru : Ya bagus sekali pertanyaannya...ada yang bisa menjawab ?(Yes nice question ... Can

anyone answer?)

.......hening......... Silence..........

Guru $\quad$ :Ok baiklah, pemuaian adalah suatu proses perubahan wujud suatu benda dikarenakan adanya pemanasan. Contoh es batu ...awalnya adalah benda padat lalu kita panaskan

maka es tersebut tidak menjadi benda padat lagi tapi jadi benda cair karena es nya

mencair. Ada yang bisa memberikan contoh lagi ? (Ok well, the expansion is a process

change in the form of an object due to heating. The example is ice cubes ... originally, 
From the data utterances (14), it can be seen that the teacher use the direct speech presentation in the form of declarative utterances in order to give an explanation about the topics being discussed at the moment. The teacher also provided opportunities for students to try to give a definition or an example in accordance with the knowledge that they have. This means that the teacher is trying to build the curiosity character on the topic that was being learnt at that time of learning and develop the students' intelligence.

\section{b. Indirect Utterances Presentation}

In everyday communication, the utterance is not only always delivered in the form of a straightforward presentation, but also sometimes conveyed behind the utterance. Delivering orders, requests, and expression of feelings are not always explicitly manifested in the form of utterance in the form of orders, requests, and expression of feelings. However, the point of the utterance is delivered in an utterance whose meaning needs to be interpreted according to the context. It also happened in the teacher's utterance in the context of teaching and learning. Teachers sometimes convey meaning using indirect utterances. For instance, declarative sentence that should serve to state or proclaim something can also be used to request or giving command as well. Likewise, the interrogative sentence which should serve to ask something can also be used to declare or tell. This may happened as teacher feels by using a form of indirect presentation utterance, the utterance expressed by the teacher to the students at that time will sound polite and courteous. The following example is the indirect utterance presentation stating the command in the form of a statement which was found in the field.

\section{Quotation [15]}

Guru : Ibu ingin kalian besok membawa dua buah botol bekas coca cola. Kita besok akan

membuat vas bunga dari botol bekas.( I want you to bring two bottles of coca cola

tomorrow. We will make a vase from the used bottles)

(Context: Spoken by teacher at the time she instructed students to bring bottles for making craft)

The utterance [15] contains commands to be issued in the form of a statement. The teacher, through the utterance, commanded the students to bring bottles of coca cola to make a vase in the next day. The utterance was not explicitly spoken teacher in a verbal commanding speech which is bringing the bottles, but it was represented by the use of the word want. In this case, the teacher told students about the items that should be taken for tomorrow. The real purpose that the teacher wanted to tell was that the students should bring used bottles for making craft.

The example of indirect utterance presentation that states a prohibition can be seen in the following example.

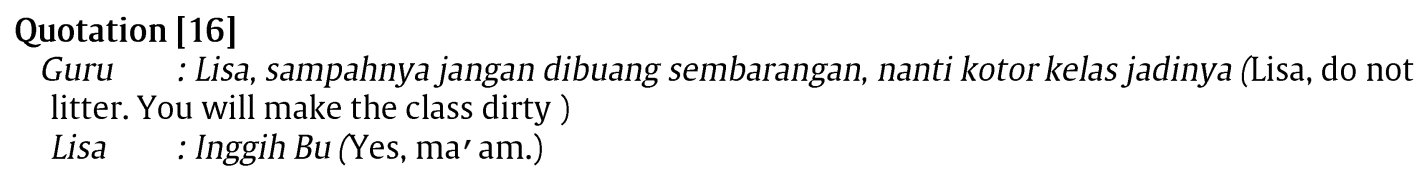

(Context: Spoken teacher at the time of making the craft when she looked around and found that one of the student's stable messy)

In the utterance above, it is visible that the teacher used a form of indirect utterance presentation. The teachers implicitly expressed a request utterance in the form of a prohibition declared by the teacher. In the qoutation [16], teacher prohibited the students from littering when she looked around the student's desk and found that the craft materials were scattered. The use of prohibition on the utterance actually had the purpose of request that the students should throw craft junks into the available bins in the classroom.

The Teachers' Speech Techniques Representing Characters Education in The Context of Early Childhood Learning Based on the research data, the teachers' speech techniques that represent the education matters can be shown in the form of the speech development techniques. It can be divided into three types, which are (1) repetition techniques, (2) explanation techniques, and (3) detailed techniques. The repetition techniques usually done by repeating the same words and the synonyms repetition. For the explanation techniques is done through the addition of words that serve as affirming the intention of utterances and limitation the scope of utterances meaning. The detailed techniques usually done by giving the detailed utterances that describes more the utterances meaning. These all speech development techniques usually used by the teachers in the process of teaching and learning that suits with the utterances contexts.

The repetition technique was used by the teacher in the utterances that representing character education in the context of learning in order to clarify something or a state repeatedly. Repetition technique is conducted by repeating the same words or the different words that have the same meaning (synonym). Here is the example of utterance repeating technique.

Quotation [17]

Guru: (1) Oval, ingatkah dengan PR?. (2) Maka kemaren sudah sangat jelas ibu padahakan harus dikerjakan PR nya.(3) Hari ini kita membahasnya. (4) Ayo Oval kerjakan!

(1) Oval, do you remember the homework? (2) I thought it was very clear that Mrs asked 
all of you have to do the homework. (3) Today, we discuss it. (4) Come on, Oval. Do it!

Murid : (5) Inggih Bu (Yes Ma' am)

(Context: Spoken when teacher gave order to one of the students at a time they checked homework given on the previous day)

In the utterance above, it is visible that the teacher used repetition technique that was expressed toward the students. The repetition technique used was the same word repetition using the name Oval, do and homework. The proper name repetition Oval that was used by the teacher intended to refer only to one student, Oval. The repetition of name Oval was done in order to make the student realized his responsibility in doing the homework. This is also applicable in the use of the word do and homework which was also repeated by the teacher in her utterance. The repetition of the words was intended to highlight the utterance meanings that was to make the student became discipline and became responsible on answering the homework given on the previous day. In order to sharpen the intention, the teacher used imperative sentence.

The explanation technique is one of the utterance technique development used by adding some additional words as the explanatory words. The additional words functioned as modifier might be in form of words with has the same meanings or modifying words in form of additional information that may function as the modifier and act as the meaning limiter of the utterance spoken. Here is the example of the teacher's speech technique by using the explanation technique.

\section{Quotation [18]}

(1)Kalau teman-temanya membaca doa, jangan bicara!. (2) Ikuti teman temannya berdoa, tujuan kita berdoa itu supaya kita pintar, supaya belajar kita bermanfaat. (3) Ayo diulang lagi berdoanya dengan betul ! ((1) If your friends are reciting the prayer, do not talk! (2) follow your friends praying. Our praying intention is that we will be smart, and our study is useful for us. (3) come on, repeat the prayer correctly)

(Context: Spoken by teacher at the initial stage before the learning process begins)

In the utterance above, the teacher used explanation as one of the speech development techniques in representing character education. In this technique, the teacher added certain words that functioned as explanatory or emphasis of the utterance intention. The above data shown that the teacher's utterance intention was to ask the students praying well, since the purpose of their prayer was to beg to Allah SWT blessing for their studying so that it would make them clever and the lesson they studied would be useful for them. The explanatory words used by the teacher were clever and useful.

The explanation development technique is an utterance presentation conducted by giving detailed description and elaborating the contents into the smaller units. The description is aimed to clarify the detail things that the students are supposed to do. The example of the explanation technique is as follows.

\section{Quotation [19]}

(1) Anak-anak..Ibu minta kalo membuang sampah itu harus pada tempatnya (2) Jangan asal buang

sampah saja. (3) Kan di depan kelas kita sudah ada bak sampah. (4) Nah tolong $\quad$ buanglah sampah ke tempat sampah yang sesuai jenisnya supaya dilihat bersih dan rapi.(5) Sekarang tolong dilihat di sekitar meja dan tempat duduknya... ada sampah tidak? Kalau ada tolong di buang dulu. (6) Nah kalau sudah bersih dan rapi baru kita mengerjakan soal latihannya.

(1) Children.. if you throw garbage, throw it into the bins (2) Do not litter. (3) There is a bin in front of the class, right? (4) So please throw garbage into bins according to its type. So it will be clean and tidy. (5) Now please look around your table and seat ... Is there any trash? If yes, please dispose it first. (6) If it is clean and tidy, we can start working on the exercise.

(Context: Spoken by teacher at the time she found that the class was less clean)

In the example above, the teacher used the development technique by means of elaboration or description the things that the students were supposed to do to keep the cleaness. At the beginning of the utterance, the teacher asked the students to dispose the trashes by separating them according to their types. After sorting the trashes, the teacher asked the students to throw them into the bins that had been provided in accordance with the types such as wet trash and dry trash. The teacher's utterance above shows how the teacher described what students must do in keeping their classroom environment. By using the explanation/description technique, it was expected that it would emphasize the teacher's intention at that time.

\section{DISCUSSION}

Based on the description of the research findings that had been described, it can be argued that the teacher's utterance in representing education character in early childhood learning was represented variously through the utterance forms and techniques. The forms of utterances and techniques representing character education were realized by the teachers based on the diversity of contexts that underlie the discourse of conversation in the classroom. In connection with the use of modalities in the utterances, Fairclough (1998: 127) explains that the modality is one of the important things of the utterance in participants' values. In connection with the use of word choice, Tannen (1994: 22) states that the use of words relating to the authority (power) and solidarity. For example, 
the use of the word greeting in the discourse of class interaction cannot be separated from consideration of the role of the participants, the speaker and the hearer.

Thus, the use of appropriate modalities to disclose the teacher's intention toward the students is necessary in order to avoid miscommunication in the classroom interaction. This is in accordance with Lyon's statement (1977) in Alwi (1990) who formulated modalities as a form of language that describes the emphasis on the content of the utterance that the speaker says. Each of the intended meanings expressed by teachers as a speaker in the context of learning with the various modality disclosers in the form of words, phrases, or clauses. This matter implies that the understanding on the modalities cannot be separated from the context of utterance in a sentence It is in the line of Yule (1996: 3) who states that pragmatics is the study of contextual meaning. It shows that the context of the utterance will determine the meaning of the utterance intended by the speaker. This is similar to the teacher's usage of the modality as the utterance representing the education character.

The use of the pronoun in the classroom discourse has its own purposes for the teachers when expressing it to the students. The goal is to reduce the social distance and build equity with students, though in fact their role and status are different in the context of learning. Holmes (2001) states that the context factors such as intonation, tone of voice, and social distance like the familiarity or the relationship between the teacher's role as speakers and students' role as hearers give effect to the utterance forms and utterance techniques used.

The purpose of pronoun as the utterance form that represents character education is to soften the illocution within the teacher's utterance in the context of the speaking, therefore it will be considered as a respectful and polite conversation. This is in accordance with the politeness strategy developed by Brown and Levinson who state that the language politeness is determined by three parameters: distance, power and rate of imposition. The pronoun usage is also used to imply that the position of teacher and the students are in one community namely classroom, as the teacher's power is low. This function as a way to make the teacher and the students' social distance to be closer, therefore the relation in the learning context becomes intimate and the process can be passed through in harmony and involves everyone.

The diction use in developing students' character in divinity, good character and sociality should be done and becomes habit of the teacher when he or she is interacting with the students in the learning context. This is because shaping students' character into the better one need habitation process, not only to be understood but also to be started early.

This is in accordance with "Ten Big Ideas" proposed by Lickona (1994) who states that the way to shape children's character is by teaching them good words and examples. By teaching them good words and examples, the children will understand the good behaviour that they should have. Teacher has a very important role in the students' character building. In teaching, he has to teach the good character to the students based on the society norm where they live. Teacher, through his motivation, creativity, guidance, and leadership, is expected to be able to share the character concept to the students well.

The use of modality, pronouns, adjectives, and adverb that develop students' character had been appropriate with the learning objective. According to the communication ethnography, the habituating process, involving and being independent are the learning result expected (Hymes, 1974). In learning context, learning objectives are not always stated formally. They might be inserted within the nurturant effects implicitly. This is in accordance with Joni (2007) who states that nurturant effects is necessary as character building software or known as soft skills.

The utilization of utterance development techniques by teachers when interacting with students in the context of learning without realizing it has also become one of the steps to achieve the learning objectives. Where the learning objective is reached, it will automatically affect the progress of education in general which affects the ideals of the nation and the state. This is in line with Megawangi (2005) who states that character education is essentially a process in order to influence students to be able to adapt as best as possible with the environment, and can lead to changes in him to be able to participate actively in public life in accordance with norms and values shared by the community. Use of the technique development of utterance in the form of the technique of repetition, description and explanation is also a communication skills of teachers in presenting ideas/messages to students, in order to create a relationship of mutual understanding which may eventually expand the cooperation in achieving the purpose desired, as well as to integrate character education in accordance with the utterance in the context of the speaking.

\section{CONCLUSIONS AND SUGGESTIONS}

Based on data analysis and discussion of research findings, can be summed up as follows.

First, in building students' character, formally the teacher's utterances can be delivered in various form of diction usage and speech presentation. Diction use involves the use of modality, pronouns, adjectives, and verbs in order to develop the students' character. The speech presentation involves direct and indirect utterances. The use of diction variety and utterance presentations is the appropriate way for the teacher to express utterance which in accordance with learning objectives and to develop the students' character as stated by Widayat (2005) that teacher's behaviour and action in uttering should be done by considering to whom the utterance is addressed, where, how, and the conducting possibility. Character education representation can also be seen when teacher uses the appropriate diction and deliver it in the right speaking context.

Second, teachers' speech techniques that represents character educations in early childhood learning can be seen in the speech development techniques. It can be divided into three types, which are repetition techniques, explanation techniques, and detailed techniques. With the use of the diversity of speech development technique, 
teachers can make the interaction to be more communicative and effective, therefore the learning objectives can be achieved while emphasizing the meaning contained in the utterance that represents a character education.

Based on this conclusion, it can be stated that the teacher's utterance which represents character education in early childhood learning is manifested in the diversity of utterance forms and utterance techniques. It is not separated from the various context where the utterances are produced. The teacher's utterances are intended to not only achieve the learning objective but also integrate the character education according to the context where they are spoken. This shows how the language skills of teachers needed in delivering learning materials and educating students with good character and nobility in accordance with the religion, the 1945 Constitution and Pancasila.

Based on the conclusions above, several suggestions can be formulated as follows. The results of the research on teacher's utterance which represents the character education in early childhood can be used as reference material in the Teaching Plan preparation (RPP/lesson plan) that contains the values of character , as knowledge and insight additional on how the teacher's utterance with character education is implemented in the classroom discourse. In addition, the results of this research can be used as a medium of understanding in introducing and instilling the character education in the context of learning.

\section{REFERENCES}

Alwi, H. (1990). Modalitas dalam Bahasa Indonesia. Yogyakarta: Penerbit Kanisius.

Brown,G., dan Yule, G.(1986). Discourse Analysis. Cambridge: Cambridge University Press.

Suwignyo, H. (2012). Wacana Kelas: Substansi, Modus, dan Fungsi Edukatif Bahasa Among. Bandung: PT Refika Aditama

Bach, K. \& Harnisch, R.M. (1979). Linguistic Communication and Speech Act. Cambridge, Mass. MIT Press.

Bohlin, K.et.al. (2001). Building Character in School: Resource Guide. California: Jossey-Bass

Chan, J.Y.H. (2013). The Role of Situational Authenticity in English Language Textbooks. In RELC Journal 44 (3), 303-317

Coullthard, Malcolm. (1985). An Introduction to Discourse Analysis. London: Longman.

Fairclough, Norman. (1998). Critical Discourse Analysis. New York: Longman

Foster, P. \& Ohta, A. (2005). Negotiation for meaning and peer assistance in second language classrooms. In Applied Linguistics 26 (3), 402-430. Retrieved form https://academic.oup.com/applij/article/26/3/402/181415/Negotiation-for-Meaning-and-PeerAssistance-in

Grundy, P. (2000). Doing Pragmatics. London: Arnold.

Goleman, D. (1997). Emotional intelligence: Why it can matter more than IQ. New York : Bantam Books.

Holmes, J. (2001). An Introduction to Sociolinguistics. New York: Longman Publishing

Hidayatullah, M.F. (2010). Pendidikan Karakter: Membangun Peradapan Bangsa. Surakarta: Yuma Pustaka.

Hymes, D. (1974). Foundation in Sociolinguistics, An Ethographic Approach. Philadelphia: University of Pennsylvan Press, Inc.

Kemendiknas. 2010. Pengembangan pendidikan budaya dan karakter bangsa (Pedoman sekolah). Jakarta: Kementerian Pendidikan Nasional, Badan Penelitian dan Pengembangan Pusat Kurikulum.

Lyons, J. (1977). Semantics. Cambridge: Cambridge University Press

Leech, G.N. (1983). The Principles of Pragmatics. London : Longman.

Lickona, T. (1994). Raising Good Children: From Birth Through the Teenage Years. New York: Bantam Books.

Megawangi, R. 2004. Pendidikan Karakter: Solusi yang tepat untuk membangun bangsa. Bogor: Penerbit Indonesia Heritage Foundation.

Mitchella, P.J., Pardinhoa, L.A., Yermakova-Aguiara, N.N., \& Meshkova, L.V. (2015). Language Learning and Intercultural Communicative Competence: An Action Research Case Study of Learners of Portuguese, in Procedia - Social and Behavioral Sciences 200 (2015) 307-312. Retrieved from https://www.researchgate.net/publication/ 282532679_Language_Learning_and Intercultural_Communicative_Competence_An_Action_Research_Case_Study_of_Learners_of_Portuguese.

Mirzaei, A. \& Forouzandeh, F. (2013). Relationship Between Intercultural Communicative Competence and L2 - Learning Motivation of Iranian EFL Learners. Journal of Intercultural Communication Research, 42 (3), 300-318, retrieved from http://www.tandfonline.com/doi/abs/10.1080/17475759.2013.816867.

Suwignyo, H. (2009) .Wacana Kelas: Substansi, Modus, dan Fungsi Edukatif Bahasa Among. Disertasi tidak diterbitkan. Malang:Pps Universitas Negeri Malang.

Rivers, W. (1987). Interactive Language Teaching. Cambridge University Press

Widayat, A. (2005). Toleransi dalam Ungkapan Tradisional Jawa, dalam Kejawen, in Jurnal Kebudayaan Jawa,Vol. 1, No 1, September 2005. 